\title{
The Defense Forces and the NGOs: A Cultural Collision or a Meeting of Minds?
}

\author{
by Michael P. Dolan*
}

Numerous conflicts since the end of the Cold War, in many parts of the world, have seen military and civilian assets deployed side by side as part of an overall UN-mandated solution. Though great cultural differences exist between the military and NGOs, a level of compromise has been demonstrated in an effort to provide solutions. The skills required to operate in alignment with the changing role of UN operations present a challenge to professional defense forces. The military officer must recognize this challenge, particularly in the area of humanitarian assistance operations, and move to meet it. To do this effectively, he/she must study the other players on stage. Ireland has international credibility, hard-won over the last fifty years of peacekeeping operations, but the Irish Defense Forces, accepting that peacekeeping and humanitarian assistance missions have changed, must also be cognizant of the dilemmas that confront both the military and NGOs in their uneasy alliance on shared turf.

The military commander will, by virtue of training and education, understand the problems faced by the military in conventional operational situations. Understanding the problems that confront NGOs is more difficult for military officers, given the limited opportunities to interact with representatives of that world. This essay attempts to lay the groundwork for greater interaction by asking the question, How can the Irish Defense Forces interact to best effect with NGOs in humanitarian assistance operations? By understanding this question and all it implies, a policy of training that incorporating inter-agency cooperation might be initiated, to the benefit of all concerned.

\section{A Crowded Stage}

"We must embark on a bold new program for making the benefits of our scientific advances and industrial progress available for the improvement and growth of underdeveloped areas.... The old imperialism - exploitation for foreign profit - has no place in our plans. What we envisage is a program of development based on the concepts of democratic fair dealing."

These words, spoken by U.S. President Harry S. Truman in his inaugural address on 20 January 1949, began the era of development. Forty years later, the

\footnotetext{
* Commandant Michael Dolan has seen United Nations service in Lebanon, Central America, and the Balkans. This essay forms part of his work in the $59^{\text {th }}$ Irish Command and Staff Course and for his M.A. in Leadership, Management, and Defense Studies at the National University of Ireland, Maynooth.

${ }^{1}$ President Harry Truman, quoted in Gustavo Esteva, "Development," in The Development Dictionary - A guide to knowledge as power, ed. Wolfgang Sachs (London: Zed Books, 1992), 6.
} 
fall of the Berlin Wall and the end of the Cold War dramatically changed the shape of the landscape on which it was practiced. By declaring certain regions underdeveloped, Truman was boldly stating that the United States was the model to which all other countries should aspire, and thus development became synonymous with Westernization, improvement, and all that was good. It was begun in Europe through NGOs closely linked, primarily financially, with the U.S. government: the International Rescue Committee (IRC) and Cooperative for American Remittances in Europe (CARE). These organizations became the humanitarian arm of the fight to halt communism. ${ }^{2}$ Although NGOs had existed before this - the Save the Children Fund (since 1919) and Oxfam (since 1942) in Britain, among others - from 1950 on there was a steady increase in the numbers of NGOs being created. In 1971, a group of French doctors rebelled at the insistence of the International Committee of the Red Cross (ICRC) on absolute public discretion and left the organization, founding Médecins Sans Frontières (Doctors Without Borders). In recent years, a startling phenomenon has been the growth in the number, size, resources, and influence of NGOs. In the main, NGOs are defined as high profile, international, and Western (often characterized as WWW: White, well-off, Western). ${ }^{3}$ Information on the U.S. Central Intelligence Agency's website indicates a growth in their numbers from 9,000 in 1981, to 16,000 in 1990, to over 23,000 in 2000. Funding for development waned in the wake of the Cold War. The Development Dictionary, edited by Wolfgang Sachs, contends that the founding premises of development were outdated by history after the fall of communism. Those in the international aid community, for whom development had become a business, began to diversify into relief, which was increasingly required by the interethnic conflicts, human tragedies, and natural disasters that came about after bilateral aid to fragile African states dried up. ${ }^{4}$ The graphic images broadcast to the living rooms of the West opened the wallets of individuals and governments. Emergency funding became a growth industry, and the number of NGOs increased.

Different NGOs - both Irish and international - are characterized by the scale of the programs they are capable of mounting and sustaining in the field. Very few NGOs are capable of mounting extensive programs on their own, and thus they form strategic partnerships in the field. For example, Trocaire associates with Caritas and works closely with Catholic Relief Services from the U.S. This allows NGOs to use their combined resources and capabilities to implement programs comparable in size to those of the bigger organizations like World Vision and CARE. Just as in military deployments, NGOs exhibit different levels of competency. Size is not always a guarantee of capability, and financial resources are not always reflected in effects on the

\footnotetext{
2 See David Rieff, A Bed for the Night (London: Vintage, 2002).

${ }^{3}$ Ibid.

${ }^{4}$ See Graham Hancock, Lords of Poverty (London: Macmillan, 1989).
} 
ground. ${ }^{5}$ Views differ regarding the commercialization of NGOs. NGOs will say they offer accountability to donors, delivering value-for-money services to the beneficiaries on behalf of the donors, while others will claim that the focus on money and expansion clouds the vision of the organization. ${ }^{6}$

The civilian agencies encountered by the military in the field can be divided, broadly, into three groups. United Nations organizations, such as the High Commissioner for Refugees (UNHCR) and the UN Development Program (UNDP), derive their mandate directly from the 190 member states and are quite hierarchal in nature. International organizations are privately funded, internationally accepted, and non-political. The International Committee of the Red Cross, based in Switzerland, is one such organization. These are less hierarchal than UN agencies, but maintain a sizeable bureaucratic structure to manage the extent and geographical displacement of projects. NGOs constitute a diverse group of organizations, delivering differing standards of assistance. The smaller ones are notable for having a very flat structure. Ranging from the enormous, with resources of many millions of dollars and large numbers of personnel, to small operations, they are funded by public donations, governmental aid, and UN organizations, or by private foundations. Their ethos may be religious, political, a combination of both, or entirely non-sectarian. NGOs in the U.S. are known as Private Volunteer Organizations (PVO). Interaction between the military and UN agencies or international organizations normally occurs at or above the formation (Brigade) level. This essay will for reasons of scope deal only with military-NGO liaison, as this is more likely to impact of the work of the military at the unit or sub-unit level. Moreover, at the lower levels of interaction, the military commander will more often encounter the smaller agencies that are the product of the recent proliferation mentioned above.

\section{The Conditionality of Ireland's Military Involvement}

The political decision to deploy Irish troops in the service of peace has been a feature of Irish military life since the UN's first deployment of military observers to the Middle East in 1948. Ireland uses its military in UN-mandated deployments as one of the four instruments of national power: diplomatic, informational, military, and economic. The "triple lock" on Irish military involvement in overseas armed peace support operations ensures that the Irish Defense Forces will not simply be used as a foreign policy tool of the government and guarantees that the military are ultimately accountable to the people of Ireland.

\footnotetext{
${ }^{5}$ Steering Committee of the Joint Evaluation of Emergency Assistance to Rwanda (JEEAR), "The International Response to Conflict and Genocide: Lessons from the Rwanda Experience,” Journal of Humanitarian Assistance (March 1996).

${ }^{6}$ See Concern Worldwide, at www.concern.ie (accessed December 2002); Hancock, Lords of Poverty.
} 


\section{Ireland's Changing Role}

Humanitarian assistance has always been a component of Irish troop-deployment missions, from the adoption of local projects to the incorporation of a humanitarian dimension into the military mandate. The Defense Forces have always been in contact with the civilian community while deployed overseas. The changing nature of these deployments, however, and the inevitable presence of civilian agencies as a part of UN-mandated missions, has brought the Defense Forces increasingly into contact with the civilian aid community. There is a necessity to maximize a level of mutual understanding so that a working relationship can be achieved. The intention of the UN Security Council to "subcontract" the military sections of mandates to regional organizations such as NATO, and to apply civilian dimensions to solutions indicates that future deployments will be far different than purely military deployments. Force composition is influenced by the scale and nature of the operation, the historical backgrounds of the participants and, in many cases, national interests. Traditionally, Ireland has been deployed along with the Nordic countries, India, Ghana, and Canada - the so-called middle powers. There is a greater likelihood that these powers will be the mainstay of any mission once a secure working environment has been created, as evidenced by the call by Denmark's Prime Minister for a deployment of troops from EU states to Iraq to help restore law and order. ${ }^{7}$

\section{Key Assumptions}

In examining the central question posed in the title of this article, I will assume certain scenarios which, given this state's alignment, are unlikely to change:

- The deployment of Irish troops, for the foreseeable future, will be on UN-mandated missions only. The passing of the Nice Treaty firmly establishes our status and was tested in Ireland's inability to participate in the first EU-led mission in the former Yugoslavia.

- Ireland's continued involvement in UN-mandated missions demonstrates the nation's acceptance of the changed nature of deployments, as outlined by the Brahimi Report. ${ }^{8}$

- The United States, as the major contributor to the funding of UN peacekeeping operations, will be in a position to exert significant pressure in formulating conditions for deployment in accordance with its own foreign policy.

- While nations operate according to different doctrines, military deployments will always be sanctioned for political reasons.

\footnotetext{
${ }^{7}$ Reported on RTE Radio, 16 April 2003.

${ }^{8}$ See Brahimi Panel on United Nations Peace Operations, The Brahimi Report, United Nations Secretary General, January 2003.
} 
- All deployments in which Ireland will participate will have a humanitarian aspect.

- Civilian affairs will be an increasingly important factor in future overseas deployment on Partnership for Peace (PfP) or Peace Support operations.

- Civil-military cooperation is not an invention of the 1990s. The delegates who attended the Hague Peace Conferences in 1899 and 1907 attempted to impose international controls on the conduct of war, and within this framework considered two strands - peacekeeping and humanitarian assistance - which have run through the century to modern times. For the greater part of the twentieth century, both of these mechanisms developed largely in isolation from each other, but the crises of the 1990s have thrown them together in an uneasy alliance. There have been instances where the two reluctant partners have worked well together, but there are also situations when the relationship has gone wrong. ${ }^{10}$

\section{The Decisive Role of Politics}

The political decision to deploy troops in a complex emergency situation is not made lightly. It is the decision of last resort, because the consequences can be so far-reaching. The international community is still having great difficulty in deciding whether, and if so, when, to intervene in both international and internal conflicts. ${ }^{11}$ What is the best mechanism for deciding to mount an international mission that has the consent of the belligerent? And, if consent is not forthcoming, when is an international intervention backed by military force justified? These questions have been the cause of much outcry over the last decade. The efficacy of intervention has been questioned, and the actions of both the military and the NGOs, who have worked in their shadow, have been scrutinized. ${ }^{12}$

\section{How Should the Military be Tasked?}

When a peacekeeping force is deployed, and is working with humanitarian agencies, what form should the relationship take, and what rules should govern it? The military are increasingly being asked to act "in support" of humanitari-

\footnotetext{
${ }^{9}$ Commodore Tim Laurence, "Humanitarian Assistance and Peacekeeping: An Uneasy Alliance," The Royal United Services Institute for Defence Studies (RUSI) Whitehall Paper Series No. 48, 1999.

${ }^{10}$ For a discussion of the former case, see John Mackinlay, "NGOs and Military Peacekeepers: Friends or Foes?" International Defense Review (July 1997).

${ }^{11}$ Robert Tomes, "Operation Allied Force and the Legal Basis for Humanitarian Interventions," Parameters (Spring 2000).

${ }^{12}$ African Rights, Rwanda: Death, Defiance, Despair (London: African Rights, 1994).
} 
an assistance, but what exactly does that mean? ${ }^{13}$ What tasks are the military being asked to undertake? Do these tasks represent the most efficient and effective use of this expensive resource? What sort of leadership and coordination should the UN be providing, both among its own agencies and peacekeeping contingents and within the wider humanitarian community? The post-conflict phase of any military deployment must be carefully planned, (Laurence, 1999) but the urgency with which this phase is treated by the military may not be mirrored by the civilian agencies, resulting in a time lag - or a funding lag - requiring that the military perform tasks more suited to NGOs. ${ }^{14}$ This is often seen by

NGOs as an infringement on their turf and is a source of friction. ${ }^{15}$

\section{When the Military and NGOs Meet}

There are three broad types of international disasters for which the international community will mobilize to provide assistance: natural disasters, technological disasters, and complex humanitarian emergencies. Military and civilian agencies will normally only encounter each other in the last instance.

Complex humanitarian emergencies have been defined by the United Nations as "a humanitarian crisis in a country or region where there is total or considerable breakdown of authority resulting from internal/external conflict and which requires an international response that goes beyond the mandate or capacity of any single agency."16

This breakdown may result in power struggles where the risk to the civilian community is either direct or indirect. The emergence of warlords or fragmentary military groupings may render the environment highly insecure, and the continuance of development work by NGOs impossible.

\section{Changed Aid Environment}

The change in the international environment in the post-Cold War era has dramatically altered the operational circumstances of humanitarian agencies. New problems and challenges have emerged. While human suffering may remain the same in character, the change in methods and responses to that suffering, especially at what may be regarded as the more political end of the spectrum, is highly significant. Benign disaster relief has given way to a more direct understanding of the human causes of these complex man-made humanitarian emergencies. Those involved with humanitarian assistance have responded to this new generation of emergencies with a more vocal approach than simply the pas-

\footnotetext{
13 See JEEAR, "International Response to Conflict and Genocide."

${ }^{14}$ Laurence, "Humanitarian Assistance and Peacekeeping."

${ }^{15}$ Directorate for Advanced Concepts, Technologies, and Information Strategies (ACTIS), "Humanitarian and Peace Operations: The NGO/Interagency Interface," report on a workshop at the National Defense University in Washington, D.C. in April 1996; available at http://www.dodccrp.org/ngoIndex.html.

${ }^{16}$ UNDHA, cited in ibid., 4.
} 
sive delivery of aid. The operational partners of humanitarian agencies have changed, and these agencies often no longer find themselves dealing with - or acting in some way subordinate to - sovereign governments. The scope for response by humanitarian agencies to deal with emergencies has affected the character of assistance and the structure of the organizations themselves. Médecins Sans Frontières and Action Internationale Contre le Faim, by virtue of being French and working inside the safe zone created by the French military in Rwanda in July 1994, were targeted by the Tutsi regime upon the departure of the French military. Their continued operation within the country was rendered non-viable. ${ }^{18}$

\section{Diversity of Agencies}

Many agencies involved in humanitarian assistance interact with military and peacekeeping operations. Attempts to quantify and analyze the various and vastly differing agencies are fraught with problems. On the face of it there are multi-lateral agencies, bi-lateral agencies, and non-government agencies, not to mention various local entities. These blanket terms cannot capture the tremendous depth and variety among these actors at every level of operations such as resources, experience, ethos, specialization, and responsibility. ${ }^{19}$

United Nations agencies have differing mandates, ethos, and resources, and their areas of responsibility can and often do conflict. Where a displaced population has not crossed an international boundary, the United Nations Development Program (UNDP) has responsibility. Where national boundaries have been crossed, the United Nations High Commissioner for Refugees takes the lead. While the United Nations created the Department of Humanitarian Affairs in 1992 to meet the evolving challenges of the post-Cold War era, its success has been mixed and its resources meager. ${ }^{20}$ Boundaries are blurred, and this causes considerable inter-agency jostling for limited resources.

The International Committee of the Red Cross's particular ethos is enshrined in international law through Henri Dunant's brainchild, the Geneva Convention of 1864. It prides itself on maintaining absolute impartiality in any conflict. It will not operate without the consent of the warring factions, and it is particularly vehement about protecting its position and propagating its humanitarian ethos. ${ }^{21}$ In modern conflicts, arriving at any agreement between all bel-

\footnotetext{
${ }^{17}$ Barry Munslow, "Angola: The politics of unsustainable development," Third World Quarterly 20:3 (1999): 551-568.

${ }^{18}$ See JEEAR, "International Response to Conflict and Genocide."

${ }^{19}$ See, for example, Rieff, A Bed for the Night; Hancock, Lords of Poverty; Concern Worldwide, op. cit.; and Goal website, at www.goal.ie.

${ }^{20}$ See Rieff, $A$ Bed for the Night.

${ }^{21}$ International Committee for the Red Cross, "The Code of Conduct for the International Red Cross and Red Crescent Movement and Non-Governmental Organizations in Disaster Relief," ICRC publication 1994, ref. 1067.
} 
ligerent parties can be especially difficult, rendering the environment particularly dangerous.

NGOs have been very much on the front lines of interaction between the various humanitarian actors and peacekeepers. They have often been vocal in their criticism of peacekeepers' involvement in humanitarian assistance. Many have also expressed their worries about what they see as militarization of aid, as peacekeepers and the military become significantly more involved in the delivery and protection of humanitarian assistance. ${ }^{22}$ It comes as no surprise that NGOs would worry about the involvement of the military in an already crowded aid marketplace. But the involvement of the military in aid delivery is open to question from a number of standpoints, such as reliability, cost-effectiveness, and the ability to collaborate in operations generally involving several UN agencies and numerous NGOs. The cultural difference is also a significant barrier to those that are fortunate enough to speak a common language. ${ }^{23}$

\section{The Fragility of the Development Continuum}

Wars no longer take place between states that feel strong enough to conquer one another but rather within states that have become so weak they implode. "Wars of the Amateurs" occur in cases where the state breaks down and the population regroups into discrete factions. Disintegration of public law enforcement, the military, and other security forces occur as well. The armed amateurs use the full range of conventional weapons for unconventional operations such as scorched earth actions, ethnic cleansing, and terrorism and intimidation. Whether there is intervention at an early stage will normally depend on whether or not national interests are involved, but the deterioration of the environment will be monitored by the NGOs on the ground as the "development continuum" is interrupted. ${ }^{26}$

This interruption is the point at which the military and civilian community may come into contact. Prior to the crisis and as it unfolds, some level of national and international development activities, involving both international agencies and NGOs, is probably taking place. As the political, economic, or security situation deteriorates, long-term development activities become more difficult or impossible to pursue, and some organizations withdraw or reduce

\footnotetext{
${ }^{22}$ Hugo Slim, "The Continuing Metamorphosis of the Humanitarian Practitioner: Some New Colours for an Endangered Chameleon," Disasters 19:2 (1996).

${ }^{23}$ See JEEAR, "International Response to Conflict and Genocide."

${ }^{24}$ Larry K. Wentz, "Peace Support Operations Cooperation, Coordination, and Information Sharing: Lessons from Kosovo," in Lessons from Kosovo: The KFOR Experience, ed. Larry Wentz (Washington, D.C.: CCRP, 2002); available at http://www.au.af.mil/au/awc/awcgate/ccrp/kosovo_section_3.pdf.

${ }^{25} \mathrm{Ibid}$.

${ }^{26}$ Kenneth J. Campbell, "Once burned, Twice Cautious: Explaining the Weinberger-Powell Doctrine," Armed Forces \& Society 24:3 (Spring 1998).
} 
their presence. Others shift their emphasis to relief efforts. The situation may deteriorate further, generating a demand for emergency international response. When the local government requests assistance or the international community, usually acting through the United Nations, decides to respond to the crisis, a massive, focused, and temporary international response, backed by military logistical and security support, takes place. The international community's goal in disaster response is to ameliorate the crisis and stabilize the situation as quickly as possible so that development efforts can recommence. ${ }^{27}$

The result of military intervention in a national humanitarian crisis that has been precipitated by internal conflict might merely delay the inevitable break-up of the state and postpone a catastrophic endgame, unless such intervention is accompanied by massive peace-building measures. For NGOs, the lag time between the suspension of development programs and the beginning of relief aid is crucial. As the situation worsens, the human tragedy unfolds and the necessity of using military intervention to restore stability outweighs the natural reticence of most NGOs. '

\section{Aid is Politicized}

Once a military deployment takes place, the provision of aid becomes politicized. This is an area in which many NGOs have difficulty. The "Code of Conduct for the International Red Cross and Red Crescent Movement and NonGovernmental Organizations in Disaster Relief," drawn up in Geneva by the Steering Committee for Humanitarian Response in 1994, was one of the first attempts by relief agencies to agree on a common frame of policy reference. InterAction, a self-coordination organization for 150 United States' NGOs, attempted to formalize in its NGO Field Cooperation Protocol procedures for the sharing of operational information by NGOs working in the same country or region. The People in Aid Code of Best Practice, developed in Britain to address concerns of British and Irish-based aid agencies, complements the other two codes mentioned here but also claims applicability to development programs. These initiatives show a deliberate attempt by NGOs to address a shortcoming identified in the aftermath of the "Great Lakes Experience," where working alongside military organizations precipitated a substantial amount of soul-searching, particularly in light of experiences in Somalia. ${ }^{28}$

\section{Changing Attitudes}

In recent years, military attitudes toward NGOs have softened. In the past, many military officers viewed NGO workers as immature, anti-military, self-right-

\footnotetext{
${ }^{27}$ ACTIS, "Humanitarian and Peace Operations."

${ }^{28}$ JEEAR, "International Response to Conflict and Genocide"; Rieff, A Bed for the Night.
} 
eous, incompetent, and unappreciative of security needs. ${ }^{29}$ NGOs describe themselves as sharing a common culture, despite their diverse sizes, ethos, organizational structures, and funding bases. InterAction sees this culture as "independent, decentralized, committed and hands-on." ${ }^{30}$ Through interaction in the field, both entities are discovering that there are areas of common ground. Initially, NGOs resisted controls placed on them by what they regarded as an overbearing military machine and relied on their neutrality to protect them in the field as they pursued their prime interests, even in cases where the military declared the situation unsafe. This changed when six ICRC delegates in Grozny, Chechnya were murdered in 1996 because of a refusal to pay for protection. The security of field workers became an issue of major consideration and was included in pre-deployment training for Irish Aid agencies through courses run by the Agency for Personnel Services Overseas.

In almost all situations where there has been a necessity for military deployment in complex emergencies, the lead nation has been the United States. In recent years the U.S. military has recognized that, if deployment in complex emergencies is coming to constitute an expanding part of its mission, it needs to have civilian agencies on its side to implement the post-conflict measures. To this end, it has undertaken a number of joint training exercises with civilian agencies. ${ }^{31}$

\section{Use of the Military}

The military realizes that, in the multi-faceted nature of modern peacekeeping or peace-enforcing missions, traditional methods of troops being inter-positioned between belligerents and working in isolation as the accepted sole authority in a conflict zone will no longer work. ${ }^{32}$ When legitimate government has broken down, there may not be unanimous consent to the military deployment. Respect for the Blue Helmets of the United Nations is no longer universal, as was shown in Bosnia and Rwanda. Stopping the conflict is still the immediate aim, but the broader focus is on holistic approaches to finding a solution. Referring to the United Nation Mission in Kosovo (UNMIK), Kofi Annan declared in his speech to the General Assembly, "The task before the International Community is to help the people in Kosovo to rebuild their lives and heal the wounds of conflict." ${ }^{33}$ The four pillars on which the success of the mission rests are:

\footnotetext{
${ }^{29}$ Daniel L. Byman, "Uncertain Partners: NGOs and the Military," Survival 43:2 (Summer 2001).

${ }^{30}$ ACTIS, "Humanitarian and Peace Operations," 9.

${ }^{31}$ See ACTIS, "Humanitarian and Peace Operations."

${ }^{32}$ Mackinlay, "NGOs and Military Peacekeepers."

${ }^{33}$ Kofi Annan, cited by Wentz, op. cit., 15.
} 
- Police and justice under the UN

- Civil administration under the UN

- Democratization and institution building led by the OSCE

- Reconstruction and economic development led by the EU. ${ }^{34}$

The military part of the mission is not mentioned. This is an admission that the job of the military in this case is to "bang heads together," and the real work will begin afterwards. This is the imperative of military-civilian cooperation.

\section{Differing Types of Military}

Military organizations differ greatly from each other. Each has its own ethos and culture, developed over many years of existence and shaped by the tasks they have performed in the service of their respective governments. The ethos of the Defense Forces in Ireland has been shaped in the same way as that of the military of all democracies in the Western world. That does not mean, however, that they are alike. Ireland, in its eighty years of existence, has never fought a conventional war and has not had to face reconstruction after such a war with the associated national pain of reintegration of soldiers into society or the loss on a grand scale of civilians or soldiers. The Defense Forces, as a volunteer force, reflects Irish society. ${ }^{35}$ This prepares it well for peacekeeping duties and humanitarian tasks. Ireland has found universal acceptance when deployed in traditional peacekeeping missions mandated by the United Nations Security Council.

In this tasking, Ireland has been referred to as belonging to the "middle-powers." ${ }^{36}$ The rise of modern sub-contracted peace-enforcement missions such as the Implementation Force in Bosnia (IFOR) and the Kosovo Force (KFOR) - calling for a combat power that Ireland cannot deliver - require that Ireland carefully consider its future role in these international missions. Should it hold itself in reserve until the bigger powers - U.S., Britain, Spain, France, Germany, and Italy - have done the heavy lifting and secured the working environment before deploying as a "second-string" military power to ensure that the environment remains stable and secure? If so, this will bring it into close contact with NGOs and will test its skills of integration and coordination.

\footnotetext{
${ }^{34}$ Wentz, ed., Lessons from Kosovo.

${ }^{35}$ Irish Defense Forces, "Leadership Manual," unpublished document, Irish Military College, Curragh, 1996.

${ }^{36}$ Mackinlay, "NGOs and Military Peacekeepers."
} 


\section{Why do the Military View the End State as Crucial?}

Because the UN does not have a standing army, it depends on its members to "lend" their military resources to international alliances or international organizations. However, while in military terms there may be a temporary transfer of operational control, there is never legally a transfer of a command. Command is an inviolate, indivisible, and non-transferable authority that stems from founding documents or national legislation and is reinforced by the laws of nation states. ${ }^{37}$ This is the critical relationship between authority, legitimacy, and accountability that provides the functional backbone for contentious operations. ${ }^{38}$ It is also seen as the main dividing line between the military and NGOs.

Such a military alliance is a temporary and voluntary association susceptible to breaking under pressure and, as such, should be recognized for its fragility. Time is of the utmost importance, and any military grouping must be deployed in force, complete its mission, and leave the theatre as soon as possible. Staying beyond the projected timeframe risks fragmenting the alliance and suffering mission creep - carrying out tasks that do not fit strictly within the military mandate. A military commander wants to bring his/her mission to a successful and speedy conclusion because maintaining a military force in the field is extremely expensive. This requires the commander to remain missionfocused, and represents one area of agreement between the military and the NGOs: both want to see the military removed from the area of operation as quickly as possible. The mission of the military is to create and sustain a secure working environment and allow the effective implementation of peace-building measures. The military is no longer required when the operating environment is secure and there are sufficient non-military assets deployed to ensure continuity in the provision of humanitarian aid. At this stage the military will willingly hand over responsibility to civilian agencies. To this end, the military appreciates the importance of the incorporation of civilian agencies into the planning process. Civil-military cooperation has grown in importance within the military as a tool of the commander to promote the successful completion of the mission.

\section{The Irish Defense Forces and Military Culture}

Though the term "military culture" is often used, remarkably little has actually been written about the culture of the Irish Defense Forces. There is a tendency, particularly by non-military people, to lump the Defense Forces into the same pot as all other military organizations. In doing this there is the danger that they might be considered the same as the U.S. or the British military, which are expeditionary by nature and are used as tools of national policy to project or secure

\footnotetext{
${ }^{37}$ John Hillen, "Peace(keeping) in Our Time: The UN as a Professional Manager," Parameters (Autumn 1996).

${ }^{38}$ Ibid.
} 
political ends. Not only are the Irish Defense Forces operationally and culturally different from other military organizations, but cultural differences also exist between units within the Defense Forces. One unit may consider excellence on the sporting field as very important, while another might emphasize success in shooting competitions. While the core values may remain the same, the symbols, rituals, and heroes of a given unit will influence its modus operandi. Because of this, the nature of Irish Defense Forces deployment overseas on peacekeeping missions is an extremely important factor from a cultural perspective.

With its strength of 10,500 , the Defense Forces has traditionally been unable to deploy a specific unit overseas and has thus formed ad hoc units to fulfill its UN peacekeeping obligations. From 1978 until 2001 a battalion was deployed every six months to South Lebanon, to serve with UNIFIL. This unit was drawn from all corps and services within the Defense Forces. ${ }^{39}$ Rifle companies were traditionally drawn, one from each brigade (formerly command) area, while the remainder was drawn from the Defense Forces at large. Each company brought with it a culture associated with the region from which it was drawn, but the overall culture of the unit was influenced by the diverse groupings and was not dominated by any one cultural group. These units were formed from volunteers and earned significant extra allowances from overseas service. In many cases, the search for professional experience was the primary motivation for volunteering for a first tour of duty overseas, but monetary reward was the prime motivator for subsequent tours.

\section{Military Views of Civilian Humanitarians}

The Irish decision, political or military, to allow the secondment of serving military officers to NGOs or to send unarmed troops as a body to work with the UNHCR was extremely innovative. The practice has since been copied by the U.S. military, with less satisfactory results. ${ }^{40}$ So in this essay care will be taken to distinguish between the two groupings of military personnel: those who have been inside the civilian aid community looking out and those who have been on the outside looking in. The perceptions vary greatly with education and cultural awareness.

Those who are particularly scathing in their evaluations of NGO performance are normally those who will take the resources of the military for granted, without ever questioning the cost involved in maintaining the military machine in place - and without considering the use to which that money, in the hands of a capable NGO, could be put. Just as military personnel will view the performance of other military contingents in the field in varying lights, so they

\footnotetext{
${ }^{39}$ Comdt. John Durnin, "The Irish Defense Forces: Options for Future Humanitarian Operations," unpublished paper, Fort Leavenworth, Kansas, 2001.

${ }^{40}$ Hugo Slim, "Humanitarianism with Borders?" paper for the ICVA Conference on "NGOs in a Changing World Order: Dilemmas and Challenges" Geneva, February 2003.
} 
should view the performance of NGOs critically, measuring them against criteria before delivering judgment. In most cases, if those who expressed opinions of the NGOs had had better understanding of those organizations, they might have viewed them in a more positive light on the ground and perhaps this in turn would have fostered a more cooperative and effective relationship.

\section{Mission and Mandate}

The difference between the missions of the military and aid agencies cannot be overstated. ${ }^{41}$ There may often be an overlap between them, but rarely will the two completely coincide. Military forces are deployed for political reasons and for political reasons alone. There is no getting around this dilemma, and the military organizations that achieve the highest levels of cooperation with civilian agencies have found that the best approach is to be honest with the NGOs about these differences yet downplay them while exploiting areas of mutual benefit. ${ }^{42}$ There are now more than 23,000 NGOs spending approximately US $\$ 7$ billion a year on aid. But half of this aid is channeled through the top ten major humanitarian NGOs. ${ }^{43}$ Because of this concentration of power and influence, it is unfair to lump all NGOs together to come up with a generic model. It will be found that the large humanitarian NGOs have a much more extensive hierarchy than the smaller ones. However, those NGOs that solicit public donations will have a number of common threads, regardless of their size or budget. Despite the disparity in resources, common cultural values manifest themselves, given the ease with which workers move between NGOs. In order that the primary question for this essay - How can the Irish Defense Forces interact to best effect with NGOs in humanitarian assistance operations? - it is imperative that the cultures of both the military and NGOs be examined, and areas of agreement and disagreement be identified.

\section{Cultural Theory}

Geert Hofstede, a professor of organizational anthropology, is regarded as one of the foremost authors on institutional cultural issues. He contends that culture is learned, not inherited, and is defined as the collective programming of the mind which distinguishes the members of one group of people from another. ${ }^{44}$ Hofstede identifies four ways in which different cultures may manifest themselves: through symbols, heroes, rituals, and values. All of these are well known

${ }^{41}$ Hugo Slim, "Military Intervention to Protect Human Rights: The Humanitarian Agency Perspective," Journal of Humanitarian Assistance (2002).

${ }^{42}$ Siobhan Kenny, "British Army brings much-needed help to Rwanda," Army Quarterly and Defence Journal 124 (4 October 1994).

${ }^{43}$ Reiff, $A$ Bed for the Night.

${ }^{44}$ Geert Hofstede, Intercultural Cooperation and its Importance for Survival (London: McGraw Hill UK, 1997). Professor Aiden Kelly reinforced these concepts in his address to the 59th Command and Staff Course of the Irish Defense Forces in February 2003. 
to the military, yet are probably rarely examined in any great detail. However, while the first three could be discarded without fundamentally affecting the organization, it is the fourth - values - that forms the cultural core of the organization. Hofstede also proposed a method to measure degrees of convergence or divergence between groups, using sliding scales from one polar extreme to another. In the context of the research question of this essay, these are extremely important. Hofstede's four metrics are:

- Power distance analysis

- Collectivism versus individualism

- Femininity versus masculinity

- Uncertainty avoidance.

Once a culture has been classified, the consequences for its ability to communicate with other cultures can be assessed. Hofstede believes strongly that different cultures can and often do work effectively together. He has demonstrated the existence of different cultures and that their differences can be measured against each other. Others have attempted to go further by proposing methods of managing different cultures. Wendy Hall has stressed the need for careful management in order to prevent cultural differences from triggering a downward spiral in terms of communication:

When cultural differences are not managed, misunderstandings occur. This leads to tension in the relationship. The tension increases suspicion of partner intent, and vulnerability is felt more strongly. The higher vulnerability leads partners to be more cautious about co-operating or using their option to withdraw, or delay. Co-operation becomes jeopardized. If co-operation is not being gained, one of the partners is sure to eventually exercise its option to withdraw. The partnership begins to flounder. Synergy is lost. The partnership fails. ${ }^{45}$

\section{Summary}

This review has centered the reader on the interactive stage of humanitarian assistance. Throughout, the resonant theme is that of culture. It colors opinion, perception, operating procedures, and the organizational psyche. Whether it will form the greatest barrier to effective cooperation or will be a force multiplier in the delivery of humanitarian assistance will be determined by how cultural differences are addressed and resolved. This requires education and, since the NGOs are vital to the "hearts and minds" phase of military interventions, the military has to do most of the learning. The next section will study the cultural

${ }^{45}$ Wendy Hall, Managing Culture (London: John Wiley \& Sons, 1995), 6. 
differences between the Irish Defense Forces and NGOs to provide an understanding of the difficulties that exist.

\section{THE CULTURAL COLLISION}

\section{The Strengths of the NGOs}

To dismiss the humanitarians as well-meaning amateurs is to seriously miss the point. As the armed forces of a sovereign country, we regard ourselves as professionals. That is not to say that we regard ourselves as being able to deliver the "shock and awe" war delivered by the U.S. military, but we do take pride in our ability to act professionally within the limits of our resources. The same applies to NGOs. In the aftermath of the Great Lakes experience, many NGOs felt the need to question some of their core values. The Humanitarian Charter was born from this questioning. ${ }^{46}$ It set the minimum acceptable standards of medical care, food, sanitation, shelter, and water supply for refugee support tasks and was adopted by 200 humanitarian NGOs, including all Irish NGOs, signaling an appreciation for the welfare of the field worker and the responsibility of NGOs to recruit the best.

The top NGOs take pride in their humanitarian professionalism, working to meet accepted standards. They tend to be innovative and radical in their approach to crises. Smaller NGOs tend to follow their lead, and this has encouraged them to strive to seek a code of best practices, entitled People in Aid. NGOs can react to crises extremely quickly, and normally have teams deployed on the ground well before the international community decides to mobilize. NGOs have flat management structures, spend relatively small amounts on bureaucracy and administration, and are generally staffed in the field by young, energetic, highly committed people. However, as the organization grows, its structure becomes less flat and results in a form of corporate hierarchy. ${ }^{47}$ Because of the need to run the organization along strict business lines in light of accounting measures demanded by donors, a natural hierarchy develops, primarily at headquarters. Other significant strengths of NGOs include:

- Independence. NGOs claim that their independence from national politics allows them to operate in areas closed to many states and military forces.

- Humanitarian Experience. The Defense Forces prides itself on its experience overseas. However, we are just novices in the humanitarian business when compared to the institutional experience of Irish NGOs such as Goal, Concern, and Trocaire, despite their short existence.

- Local Knowledge. A common NGO criticism of the military is that

\footnotetext{
46 The Sphere Project, Humanitarian Charter and Minimum Standards in Disaster Relief, ed. Isabel McConnan (London: Oxfam Publications, 2000).

${ }^{47}$ See, for instance, World Vision International, at http://www.worldvision.org.
} 
they lack essential local knowledge, having usually arrived in the theatre well after a crisis has occurred. ${ }^{48}$ NGOs will usually have been in the area for some time carrying out development projects, and will have significant local knowledge. Problems arise with regard to sharing this information with the military, as NGOs feel that passing information to the military will compromise their impartiality.

- Long-term Perspective. NGOs split their roles between short-term relief efforts and long-term development aid. The latter will normally flow from the former, or the former will occur when events cause a break in the development continuum. For this reason, they tend to keep an eye on the long-term consequences of any relief efforts. In Rwanda in 1994, military contingents attempted to deliver living standards in excess of those available in the home villages. The provision of abundant water supplies and a lowering of mortality rates served to perpetuate existence of the refugee camps. NGOs tend to spread the aid more widely to avoid concentrating on a relative minority of refugees. ${ }^{49}$

These strengths single out the major NGOs as essential operating partners for the military during complex emergencies. There will always be cultural differences, but if these are understood from the outset - and if each group can appreciate the strengths of the other rather than focus on the perceived weakness - then inter-agency cooperation will be that much more effective. This mutual understanding can be best achieved through education and joint training.

Potential serious impediments to such cooperation can be seen from comparing the above-mentioned strengths with the operational aims of any military agency deployed into a complex emergency. The following figure shows where these differences are most pronounced:

Figure 1: NGO vs. Military

\begin{tabular}{|l|l|}
\hline NGOs & Military \\
\hline $\begin{array}{l}\text { Independence (Individualist) as } \\
\text { organizations }\end{array}$ & $\begin{array}{l}\text { Collectivist in terms of operating } \\
\text { procedures }\end{array}$ \\
\hline $\begin{array}{l}\text { Engages with local population - generates } \\
\text { trust }\end{array}$ & $\begin{array}{l}\text { Concentration on force protection } \\
\text { separates them from local popula- } \\
\text { tion - generates mistrust }\end{array}$ \\
\hline Extensive humanitarian experience & Limited humanitarian experience \\
\hline Local knowledge & Intelligence needs \\
\hline Long-term perspective - focused on task & Focused on timescale and end state \\
\hline Flat organization & Hierarchical organization \\
\hline
\end{tabular}

${ }^{48}$ ACTIS, "Humanitarian and Peace Operations."

${ }^{49}$ JEEAR, "International Response to Conflict and Genocide." 


\section{Cultural Picture}

Applying Hofstede's cultural dimensions, the Irish Defense Forces are seen to be a generally masculine and collectivist organization emphasizing teamwork, with strong tendencies for uncertainty avoidance (a proclivity for detailed advance planning) and large power distance (extensive hierarchy). Is it possible to describe the NGOs so succinctly?

Hofstede writes of the cultural type indicators displayed by different organizations and which, sometimes subconsciously, are used to define their identity. At the heart of these indicators - beneath the symbols, rituals, and heroes - lie their core values. Among the essential values accepted by Defense Forces leaders are:

- Loyalty - to superiors and subordinates

- Duty - obligation to act in the best interests of society and subject to the democratically elected government of the state

- Integrity - being seen to act with honor, honesty, fairness, and selflessness

- Courage - both physical and moral..$^{50}$

In the civilian realm, core values differ from NGO to NGO, but most would claim to cherish the following key concepts:

- Neutrality

- Impartiality

- Absolute adherence to the humanitarian imperative

- Independence. ${ }^{51}$

\section{Cultural Contrast - the Cultural Cross}

The most obvious differences between those who work for the military and NGOs involve gender and generation. NGO field workers are typically far younger than the officers with whom they will have to interact, and a high proportion of them are female. ${ }^{52}$ Less obvious cultural differences have been identified by Hofstede, and the figures that follow have been adapted from his work in an attempt to contrast the cultures of NGOs with the accepted culture of the Irish Defense Forces according to his four cultural dimensions: power distance; collectivism vs. individualism; femininity vs. masculinity; and uncertainty avoidance. Hofstede shows how a "cultural cross" can be constructed from observed data as a tool for comparison. I have created this cross, combining analyses of each of Hofstede's four cultural dimensions as they are borne out in

\footnotetext{
${ }^{50}$ Irish Defence Forces, "Leadership Manual."

${ }^{51}$ ACTIS, "Humanitarian and Peace Operations."

52 Slim, "Continuing Metamorphosis of the Humanitarian Practitioner."
} 
NGOs and military organizations. The study is hardly scientific, as it is based on experience gained from fifteen months working as an aid worker and three periods working in a civilian capacity as an election monitor in Bosnia. However, a survey of the $59^{\text {th }}$ Command and Staff Course of the Irish Defense Forces has provided the data for the military position, and the NGO position has been plotted through observation of civilian organizations with which I have been involved.

\section{Figure 2: Power Distance}

\begin{tabular}{|l|l|l|}
\hline & Small Power Distance (-) & Large Power Distance (+) \\
\hline A & $\begin{array}{l}\text { There should be interdependence } \\
\text { between less and more powerful } \\
\text { people. }\end{array}$ & $\begin{array}{l}\text { Less powerful people should be } \\
\text { dependent on the more powerful } \\
\text { Clear polarization between groups. }\end{array}$ \\
\hline B & Decentralization is popular. & Centralization is popular. \\
\hline C & $\begin{array}{l}\text { Subordinates expect to be } \\
\text { consulted. }\end{array}$ & $\begin{array}{l}\text { Subordinates expect to be told } \\
\text { what to do. }\end{array}$ \\
\hline D & $\begin{array}{l}\text { Organizational hierarchies are } \\
\text { established for convenience only. }\end{array}$ & $\begin{array}{l}\text { Hierarchies are vital for } \\
\text { efficient management. }\end{array}$ \\
\hline E & $\begin{array}{l}\text { The ideal boss is a resourceful } \\
\text { democrat. }\end{array}$ & $\begin{array}{l}\text { The ideal boss is a competent } \\
\text { commander. }\end{array}$ \\
\hline F & $\begin{array}{l}\text { Privilege and status are frowned } \\
\text { upon. }\end{array}$ & $\begin{array}{l}\text { Privilege and status are } \\
\text { expected and popular. }\end{array}$ \\
\hline
\end{tabular}

\section{Power Distance}

The table indicates that there is a significant cultural gap across all six power distance indicators. In general terms, the military exhibit very strong power distance traits, through emblems, rituals, and rank. This is normal in a large hierarchal organization where power is centralized. On the other hand, NGOs, aspiring to very flat organization, show much weaker power distance tendencies. Hofstede indicates that weak power distance indicators are present in amateur associations and non-profit organizations possessing flat organizational structures. He also believes that inter-organizational friction is most likely to be caused by groups indicating a strong power distance dimension. This has, from time to time, shown itself in units serving in Lebanon as an "us vs. them" perception, dividing the headquarters from the companies. 
Figure 3: Collectivism vs. Individualism

\begin{tabular}{|l|l|l|}
\hline & Collectivist (-) & Individualist (+) \\
\hline A & $\begin{array}{l}\text { Identity is based on the social } \\
\text { network in which one exists. }\end{array}$ & Identity is based on the individual. \\
\hline B & $\begin{array}{l}\text { People taught to think in terms of } \\
\text { "we." }\end{array}$ & People taught to think in terms of "I." \\
\hline C & Seek harmony, not confrontation. & $\begin{array}{l}\text { Speaking one's mind is a sign of an } \\
\text { honest person. }\end{array}$ \\
\hline D & $\begin{array}{l}\text { Employment relationships } \\
\text { regarded as a family link - strong } \\
\text { moral dimension. }\end{array}$ & $\begin{array}{l}\text { Relationships based on contract and } \\
\text { mutual advantage. }\end{array}$ \\
\hline E & Management is of groups. & Management is of individuals. \\
\hline F & $\begin{array}{l}\text { Relationship is more important } \\
\text { than task. }\end{array}$ & $\begin{array}{l}\text { Task is more important than } \\
\text { relationship. }\end{array}$ \\
\hline
\end{tabular}

\section{Collectivism vs. Individualism}

It is difficult to extract any real cultural gap in this area. It is as I expected: both NGOs and the military reflect the society from which both groups come. Both groups display collective and individualistic traits to some degree or another. The degree of individualism in the military will increase with promotion as the individual takes responsibility and assumes a duty of care for the group. In NGOs, there is less of a feeling of operating as part of a cohesive group because of the diversity of task that must be performed by a small team. This requires exceptional teamwork, solution-oriented personalities, and low tolerance for egos.

\section{Figure 4: Femininity vs. Masculinity}

\begin{tabular}{|l|l|l|}
\hline & Feminine (-) & Masculine (-) \\
\hline A & Welfare society ideal. & Performance society ideal. \\
\hline B & The needy should be helped. & The strong should be supported. \\
\hline C & $\begin{array}{l}\text { Relatively high number of female } \\
\text { employees. }\end{array}$ & $\begin{array}{l}\text { Relatively small number of female } \\
\text { employees. }\end{array}$ \\
\hline D & $\begin{array}{l}\text { Peace and harmony achieved } \\
\text { through dialogue and example. }\end{array}$ & $\begin{array}{l}\text { Peace enforced through capacity to } \\
\text { coerce. }\end{array}$ \\
\hline E & Pacifistic. & Militaristic. \\
\hline F & $\begin{array}{l}\text { Equality means granting equal } \\
\text { status and rights to all. }\end{array}$ & $\begin{array}{l}\text { Equality means being forced to } \\
\text { admit non-conformists into the } \\
\text { group. }\end{array}$ \\
\hline
\end{tabular}




\section{Femininity vs. Masculinity}

An organization can exhibit masculine or feminine traits, regardless of whether or not either gender dominates the workforce. Some traits generally accepted as being masculine in organizational terms are emphases on earnings, recognition, advancement, and challenge, whereas feminine traits are those that stress relationships with one's manager, cooperation, living area, and employment security. When military organizations and NGOs are compared - particularly with regard to recognition vs. cooperation - the experience of those surveyed would indicate that, while NGOs may court attention and recognition in the media, the individual volunteers within those same organizations shun publicity.

Given the nature of the Irish Defense Forces, it is not surprising that a significant gap presents itself for this set of indicators. However, while the gap exists, it is not so great that overcoming it should prove impossible.

\section{Figure 5: Uncertainty Avoidance}

\begin{tabular}{|l|l|l|}
\hline & Weak Uncertainty Avoidance (-) & Strong Uncertainty Avoidance (+) \\
\hline A & Few and general regulations. & Many precise regulations. \\
\hline B & $\begin{array}{l}\text { If rules cannot be respected, } \\
\text { they should be changed. }\end{array}$ & $\begin{array}{l}\text { If rules are broken, offenders } \\
\text { should be punished. }\end{array}$ \\
\hline C & Dissent is acceptable. & Dissent is unacceptable. \\
\hline C & Tolerance and moderation prevail. & There is only one right way. \\
\hline E & High tolerance of ambiguity. & Low tolerance of ambiguity. \\
\hline
\end{tabular}

\section{Uncertainty Avoidance}

This is the cultural dimension that exhibits the widest cultural gap between the two types of organizations. The nature of military planning is to strive to reduce, to the absolute minimum, what Clausewitz referred to as "friction" in operations. Detailed scenarios are played out in the form of war-gaming so that the military can be ready for all eventualities. The military's near obsession with order, clarity, conservatism, and discipline fits uncomfortably with the NGO's more adaptable, multi-task responsiveness, and flexible, democratic, and tolerant working environment. The nature of NGO work does not allow for the luxury of personnel to plan to the same detail as that practiced by the military. In addition, due to their limited financial and human resources, NGOs cannot build into their operations a sufficient level of personnel redundancy, an ability that allows the military react to the unexpected. 
Figure 6: The Cultural Cross

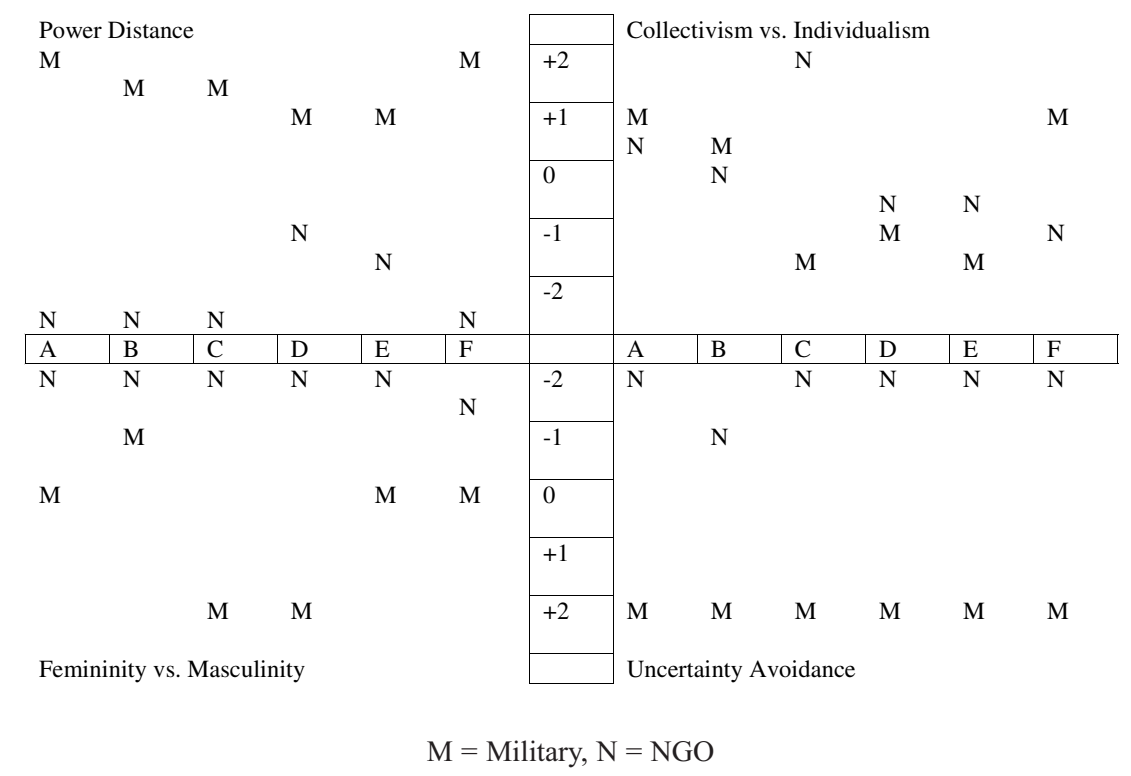

At a glance, it is apparent that the greatest degree of discord between the two types of organization is in the power distance and uncertainty avoidance dimensions, whereas the other two sectors indicate a closer match. This is to be expected, because the Defense Forces have never fought a war and is firmly rooted in Irish society. This full integration into Irish society means that the values of society are reflected in the military, as they are in the NGOs, which are equally rooted in Irish culture and society. However, the nature of the organization and the training that the members undergo account for the military positions where divergences exist.

The Cultural Cross confirms that there is a significant level of cultural dissonance between the two camps with regard to power distance and uncertainty avoidance, but a narrower, less well-defined gap between the other two dimensions. Here it is apt to quote Hofstede:

The most problematic [relationships] are between groups, which score highly on Uncertainty Avoidance ... and on Power Distance. In a world kept together by inter-cultural co-operation, such cultural groups will certainly not be forerunners. They may have to be left alone for some time until they discover that they have no choice but to join.

${ }^{53}$ Hofstede, Intercultural Cooperation, 237-38. 
This implies that it is the military's particularly strongly defined organizational traits that are likely to be the cause of cultural friction rather than the NGOs' looser, less sharply defined characteristics. If the military wants to be a forerunner in multi-agency operations, then perhaps it needs to take a close look at its own internal structures and processes first.

\section{Ramifications for the Clash of Cultures}

When these cultural differences confront each other on the ground, the inability to communicate effectively, caused by a lack of mutual understanding, creates tension. This tension manifests itself in five distinct areas: expectations, perceptions, resources, missions, and values. ${ }^{54}$ Any examination of instances where inter-agency cooperation has failed will point to these areas.

\section{Expectations}

In Rwanda in 1994, some aid agencies believed that the U.S. forces were overly concerned about force (self) protection and committed too many troops to this aspect of their deployment. They felt that more could have been done if more troops had been deployed on humanitarian tasks. On the other hand, many military planners fully expected that civilian agencies would have planning cells to mirror the military's in terms of size and capability. Each failed to realize the capability of the other. ${ }^{55}$

\section{Perceptions}

The most obvious differences between the NGOs and the military in Rwanda involved gender and age. NGO field workers are typically far younger than the officers with whom they interact, and a high proportion of them are female. This poses a challenge to cooperation, as a colleague of mine in Rwanda angrily pointed out after a less than fruitful visit to a British field hospital: "If I can credit his experience and take him seriously, why can't he give me the same credit?" (This aid worker had previously worked in Sudan, Somalia, Ethiopia, and Angola.) In any organization where promotion is achieved through a mixture of ability and time of service, it is easy to believe that wisdom comes with age. Where that organization is predominantly of one gender, there exists the danger of members of the opposite sex - particularly younger members - being taken less seriously. This represents a level of immaturity that must be addressed within the military if inter-agency cooperation is to succeed.

\section{Resources}

The ability of the military to mobilize and project resources into the Great Lakes Region in Rwanda in 1994 was the envy of many civilian aid agen-

\footnotetext{
${ }^{54}$ Slim, "Humanitarianism with Borders?"

${ }^{55}$ JEEAR, "International Response to Conflict and Genocide."
} 
cies. But when the resources were in theatre, there was resentment at the size of the military footprint, leading to accusations of waste, given the level of operational redundancy built in to the forces. There was a legitimate fear that the level of provision of services by the military in the refugee camps would be unsustainable after their departure. In October 1994, Oxfam expressed this fear eloquently in Gikongoro, Rwanda. The British force, as part of its Operation Gabriel, put forward a plan to pipe water from a river three miles uphill to large holding tanks where it would be treated before being distributed under gravity to service the Kibeho refugee camp with its population of 60,000. Oxfam argued that the scale of the planned operation, though feasible given the British military's resources, would create a dependency that could not continue to be satisfied after their departure. The British force was well served by its civil-military cooperation officer, who successfully scaled back the operation, deferring to the experience of the Oxfam field worker. This major - a dentist by profession - was an excellent communicator, broad-minded in his approach and keen to understand the needs of the NGOs with whom he was dealing.

\section{Missions}

The essential difference between the two types of organizations' missions will always be a fundamental cause of friction between NGOs and the military. Aid agencies will always strive to meet the needs of the humanitarian imperative, while the military will always work towards their masters' goals and a quick exit, and it is by definition virtually impossible for these missions to precisely coincide.

\section{Values}

Values go to the core of an organization's existence, and studying them renders an organization very uncomfortable. In the aftermath of the Great Lakes experience, civilian aid agencies invested heavily in this type of study. They had provided aid to the perpetrators of the Rwandan genocide. Their actions in providing this aid had perpetuated the camps in Goma, facilitating attacks into Rwanda by those who controlled the Hutu refugees in Goma. This in turn precipitated attacks from within Rwanda into the refugee camps, resulting in even more bloodshed. Not acknowledging the politics of the situation meant that short-term aims had been achieved at the expense of long-term stability. ${ }^{56} \mathrm{On}$ the other hand, aid agencies are skeptical of the humanitarian efforts of the military, when they can so easily deliver aid with war materiel.

From the military perspective, regardless of the terms in which they may couch it, civil-military cooperation is simply yet another tool to assist the achievement of the end state of the military mission. Much was made of the

56 JEEAR, "International Response to Conflict and Genocide;" Peter Uvin, "Difficult choices in the new post-conflict agenda: The international community in Rwanda after the genocide," Third World Quarterly 22:2 (2001): 177-189. 
progress of the British ship HMS Galahad towards Iraq in the aftermath of the 2003 invasion and the efforts made to ensure that its route was mine-free as it brought 500 tonnes of humanitarian aid to the beleaguered population of southern Iraq. Barely a comment was made regarding the 7,500 tonnes of aid that had been shipped by land that were being held by the U.S. forces outside Baghdad while waiting for the situation to improve. In this light, is it difficult to believe that the Galahad did not have a mixture of military and humanitarian materiel? This is the prime reason why civilian aid agencies are suspicious of the involvement of military in purely humanitarian tasks.

\section{Summary}

It is obvious that a cultural chasm exists between the military and NGOs. When examined in specific terms, however, a spectrum is seen to emerge in the case of both. At the extreme ends of the spectrum in each case, indications suggest that the compromise required for a successful partnership is not forthcoming. Encouragement is found in the middle ground, where rigidity has given way to pragmatism, allowing an uneasy alliance to emerge in some complex emergencies.

NGOs bring strengths to their theatres of operation that cannot be matched by the military. Depth of contact with the target population, local knowledge, humanitarian concern, implementation policies, and flexibility in approach all work to favor the NGO elements of the partnership. On the other hand, the heavy muscle that the military brings gives it the ability to impose a secure working environment to allow for the restoration of the development continuum. The catastrophic events that followed the genocide in Rwanda in 1994 rendered the aid community incapable of meeting the demands placed on it. The airlift capability delivered by the U.S. and the level of security created by the French military presence facilitated containment of the situation until control could be handed back to the aid community. UN-mandated operations in Bosnia, Kosovo, East Timor, and Sierra Leone have seen both NGOs and the military sharing the same turf.

As many of these situations exemplify, the nature of conflict has changed. An accommodation will have to be reached in order to pursue best practices in delivering assistance to those on whose behalf both entities were deployed. Any accommodation will require compromise, vision, and flexibility on both sides. Holding tightly to traditional viewpoints serves only to create entrenched positions. Exploration of each other's culture may create a climate of understanding in which the needs of the beneficiaries can be best met.

For the military, implementing the commander's intent means devising mechanisms or tactics by which the operation can be successfully carried out in pursuit of that intent. To develop tactics leading to successful interaction with NGOs in humanitarian assistance operations, a Defense Forces offi- 
cer must study the players and identify the strengths and weaknesses of each. This will include, as an integral part of the process, studying the culture and nature of the NGOs with which he/she will interact.

\section{CONCLUSIONS AND RECOMMENDATIONS}

This essay has explored the cultural differences between the military and NGOs, and the difficulties that arise because of these differences when working in the same theatre. NGOs form only one element in the overall context of civilmilitary cooperation, and it is necessary for the military to be able to work together with many other non-military agencies. Hofstede's cultural cross shows that the military's organizational traits are likely to be the primary cause of friction in their interactions with NGOs. Therefore, to be effective, the military organization must adapt its own structures and rituals. This must be done from a position of knowledge, which will require careful study of the cultural differences between the military and NGOs. However, the diversity and sheer number of NGOs, each proclaiming its absolute independence and distrust of the military, means that they will always be a major concern for a military commander when they share the same stage. Civil-military cooperation is a tool designed to provide operational freedom. Just like any other tool, it provides best results when its capabilities are fully understood.

\section{Conclusions}

The military and NGOs make strange bedfellows. It takes a desperate situation to force two such apparently distinct organizations into such a necessary and symbiotic partnership. The dynamics of warfare and international politics have changed so much in the past decade that such situations will become increasingly commonplace. If the Irish Defense Forces is to build on its strengths, it may find itself having to take a leading role in multi-agency coordination. To do this, it must be proactive in finding out about the nature of those agencies with which it will work. The impetus for this must come from the top down, in the form of a lead from government on policy. Defense Forces chiefs need to have doctrine developed that demonstrates an in-depth knowledge and appreciation of the issues involved and the capabilities necessary to deliver success.

If the Defense Forces is to take a proactive role in coordinating interagency issues during future operations, it must do so via an NGO-friendly interface. NGOs will respond better to a more collegial and relaxed management style, reflective of their culture, than to the traditional hierarchic and autocratic approach that works for the military. The attitude demonstrated by the British major in resolving the water issue mentioned above is exactly what is needed in order to ensure that NGOs can be successfully engaged by the military. Each respondent to my survey has indicated that he/she felt that the experience of working with NGOs tested and improved military skills and that the deploy- 
ment was correct and had no adverse effect on our military capability.

Above all, the military needs to accept that, although it can bring key skills to a complex emergency situation (e.g., communications assets, logistics, engineering and medical support), it is not a humanitarian organization and must never masquerade as one. In fact, it is often quite justifiably regarded as being amateurish and even dangerously incompetent in the delivery of humanitarian aid by many of the professional aid NGOs.

\section{Recommendations}

PfP tasks require that the Irish Defense Forces host a joint PSO exercise in 2003. This will have a level of NGO input. In 2002, UNTSI held a week-long course for international press personnel. The inclusion of non-military personnel in these events must be welcomed. However, these events are often cases of the non-military being swamped by the military and, as such, the military is teaching rather than learning. An element of training is required for the military in which they will not be the dominant grouping.

\section{Doctrine}

A more professional, doctrinally-led military approach must be adopted in inter-agency cooperation issues. The current rather ad hoc system, while it might seem successful, will always depend on the individual who happens to be selected for the appointment. Civil-military cooperation is still relatively stuck on the sidelines as an operational planning issue.

\section{Education and Training}

The Irish Defense Forces is well equipped with the generalist skills of civil-military cooperation, but when it comes to the specialist, there is a need for training at all levels appropriate to the level of exposure to civilian agencies that an individual is likely to encounter. It is particularly important that our junior officers and senior NCOs be exposed to the NGO culture so that they are not thrown off by the experience when deployed overseas. This will require interaction with NGOs, their involvement in military courses, and the involvement of military officers in NGO courses.

In keeping with the teaching of military forces from whom we borrow a certain amount of our doctrine, training members of the Defense Forces Reserve in this area may be appropriate as well. The implications are far-reaching. It will be necessary to revisit Defense Forces policy of having only personnel of the Permanent Defense Force serve overseas. Members of the Reserve, because of the part-time nature of their employment, exhibit cultural differences when compared with career military men and women. An examination of the culture of reservists may find them well suited for civil-military cooperation work. Exposure to alien cultures will educate everyone involved, and will 
require individuals to examine their own culture. There will be forced compromise in many areas to ensure harmonious co-existence. However, the potential benefits far outweigh the threat to the military.

\section{Guide Book}

Increased awareness of NGOs and their culture can be enhanced by the provision of a regularly updated guidebook about working with aid agencies. Aimed at the unit and sub-unit level, such a guide could be used to explain the roles of NGOs, their motivation, funding, technical standards, and their operating strengths and weakness, as well as their cultural differences. It could also give advice on management and coordination issues. The attitude survey used in this analysis asked if there was a requirement for additional pre-deployment training. Of those who believed such a requirement existed, the deficit was seen to be in the areas of understanding of civilian agencies and technical requirements of refugee support operations rather than coping with emotional stress.

\section{Cultural Awareness}

The Irish Defense Forces needs to study its own cultural strengths and weaknesses to assess how this effects inter-agency cooperation in multi-agency environments. Ingrained assumptions about the Defense Forces' culture, values, and ethical standards need to be examined and, where necessary, revised to present a more effective interface with future civilian partners. As a Defense Force, we have certain strengths in this arena - service with multinational forces such as SFOR, Force Mobile Reserve of UNIFIL, and INTERFET has shown the importance of understanding the culture of our operating partners. Planned deployment within a Finnish brigade in Kosovo will move this process forward, but the Finnish military culture must be studied to promote efficient and effective operating procedures, just as the Finns will be studying our culture.

\section{Irish Neutrality}

The area of civil-military cooperation is one to which Irish troops are suited. Our natural inclination towards problem solving and our ability to communicate could help us get established in this niche market. Ireland's neutrality could be exploited in dealing with NGOs, as we carry no colonial baggage. We have enjoyed universal acceptance in the area of peacekeeping, and so, with proper education and training, there is no reason to believe that we would not find acceptance among NGOs as facilitators.

If the Defense Forces is to build on its success of the last fifty years of peacekeeping, it must be aware that the arena into which it will deploy in the future has changed totally from that which it occupied during its first fifty years in the service of peace. To take a leading role in future deployments, a serious examination of its approach to interaction with civilian agencies is vital. A more integrated, less ad hoc, approach is needed, and this requires high-level doctri- 
nal guidance before it can be made to work. The Defense Forces also needs to be more proactive and flexible and must be honest about its own internal barriers to effective inter-agency cooperation. Before the Defense Forces can learn how to interact with NGOs, it must accept that a need to learn exists.

The attitude survey pointed to the lack of debriefing of returning soldiers, a lack of employment of individuals in roles where this experience could be shared, and the feeling that education about civilian agencies and the technical support requirements of refugee support operation would greatly benefit any officers involved in this type of operation. But this information is eight years old. The landscape has changed, and it requires that this aspect be treated with greater urgency than before. This will require an amount of humility - a quality not normally associated with masculine organizations. It must address the cultural differences that are most apparent: power distance and uncertainty avoidance. It must be accepted that ability is not the sole preserve of experience, and that the 26 year-old nurse with field experience deserves to be taken seriously.

\section{Areas for Further Study}

This essay has looked at the NGO culture from the perspective of military officers who have operated within the NGO community, rather than the perspective of those on military deployments who have had limited interaction with NGOs. I believe that a study of how this experience affected these officers' views of military culture would prove valuable if the same "embedding" process were to be considered again.

In researching this thesis, some additional questions presented themselves:

- What role should the Defense Forces seek in modern peacekeeping and humanitarian assistance operations? Should it have a generalist approach, or should it aim to provide resources to niche markets?

- Should the Defense Forces even be involved in overseas missions, given that it would appear to lack the teeth or the culture to perform to best effect in Chapter 7 Missions?

- Is Ireland's future in peacekeeping and humanitarian assistance operations bleak because of the Triple Lock? Is there a possibility of participation on EU-led missions that do not have a UN mandate? If so, how can this be achieved?

I believe that any one of these questions would benefit from further study and that a rigorous treatment of the subject would make a considerable contribution to the Defense Forces' body of knowledge in this area. 


\section{Bibliography}

Byman, Daniel L. "Uncertain Partners: NGOs and the Military." Survival 43, no. 2 (2001).

Campbell, Kenneth J. "Once burned, Twice Cautious: Explaining the Weinberger-Powell Doctrine." Armed Forces \& Society 24, no. 3 (1998).

Esteva, Gustavo. Development In The Development Dictionary - A guide to knowledge as power. London: Zed Books, 1992.

Hall, Wendy. Managing Culture. London: John Wiley \& Sons, 1995.

Hancock, Graham. Lords of Poverty. London: Macmillan, 1989.

Hillen, John. "Peace(keeping) in Our Time: The UN as a Professional Manager." Parameters (1996).

Hofstede, Geert. Intercultural Cooperation and its Importance for Survival. London: McGraw Hill UK, 1997.

Humanitarian and Peace Operations: The NGO/Interagency Interface In report on a workshop at the National Defense University in Washington, D.C. Directorate for Advanced Concepts, Technologies, and Information Strategies (ACTIS), 1996.

Kenny, Siobhan. "British Army brings much-needed help to Rwanda." Army Quarterly and Defence Journal 124 (1994).

Laurence, Tim. Humanitarian Assistance and Peacekeeping: An Uneasy Alliance In Whitehall Paper Series. The Royal United Services Institute for Defence Studies (RUSI), 1999.

Mackinlay, John. "NGOs and Military Peacekeepers: Friends or Foes?" International Defense Review (1997).

McConnan, Isabel. Humanitarian Charter and Minimum Standards in Disaster Relief In The Sphere Project. London: Oxfam Publications, 2000.

Munslow, Barry. "Angola: The politics of unsustainable development." Third World Quarterly 20, no. 3 (1999): 551-568.

Rieff, David. A Bed for the Night. London: Vintage, 2002.

Rwanda: Death, Defiance, Despair. London: African Rights, 1994.

Slim, Hugo. "Military Intervention to Protect Human Rights: The Humanitarian Agency Perspective." Journal of Humanitarian Assistance (2002).

Slim, Hugo. "The Continuing Metamorphosis of the Humanitarian Practitioner: Some New Colours for an Endangered Chameleon." Disasters 192, no. 2 (1996). 
Slim, Hugo. Humanitarianism with Borders? In paper for the ICVA Conference on "NGOs in a Changing World Order: Dilemmas and Challenges". Geneva, 2003.

The Brahimi Report. United Nations Secretary General, 2003.

The Code of Conduct for the International Red Cross and Red Crescent Movement and Non-Governmental Organizations in Disaster Relief. International Committee for the Red Cross, 1994.

The International Response to Conflict and Genocide: Lessons from the Rwanda Experience In Journal of Humanitarian Assistance. Steering Committee of the Joint Evaluation of Emergency Assistance to Rwanda (JEEAR), 1996.

Tomes, Robert. "Operation Allied Force and the Legal Basis for Humanitarian Interventions." Parameters (2000).

Uvin, Peter. "Difficult choices in the new post-conflict agenda: The international community in Rwanda after the genocide." Third World Quarterly 22, no. 2 (2001): 177-189.

Wentz, Larry K.. "Peace Support Operations Cooperation, Coordination, and Information Sharing: Lessons from Kosovo." In Lessons from Kosovo: The KFOR Experience. Washington, D.C.: CCRP, 2002. 